Chapter 23

\title{
Potential of Different Tissue Engineering Strategies in the Bladder Reconstruction
}

\author{
Sara Bouhout, Alexandre Rousseau, \\ Stéphane Chabaud, Amélie Morissette and \\ Stéphane Bolduc
}

Additional information is available at the end of the chapter

http://dx.doi.org/10.5772/55838

\section{Introduction}

Organism's functions are provided by different biological apparatus and one of them is essential for maintaining the integrity of this system. Indeed activities of each organs lead to the cellular production of metabolites. These metabolic products are discharged into the blood system to be supported by the urinary apparatus. The purification of the blood is essential to preserve the homeostasis of the organism and the blood pressure. The upper urinary tract is composed of kidneys which filter the blood to evacuate the excessive water, ions and toxic metabolic products. Then, this mixture called terminal urine is transported in the lower urinary tract by the ureters. The lower urinary tract consists of the bladder which stocks the urine until its evacuation by the urethra. The terminal urine is cytotoxic because of its composition of nitrogenous and potential carcinogenic elements, also its $\mathrm{pH}$ which varies between 4.5 and 8.3 $[1,2]$. Therefore, the storage of urine need to be safe, this is why the bladder possesses two specific characteristics.

Firstly, the bladder wall is watertight in order to prevent the urine from seeping through the different tissue layers and damage their structure. Secondly, the bladder is compliant in order to keep a low pressure during the urine filling, and prevent reflux towards the upper urinary tract which could lead to kidneys failure. Thereby, the bladder is able to adapt its capacity to the volume of the accumulated urine. These properties are entirely related to the nature and the structure of different tissues which compose the bladder wall (Figure 1). As shown in the figure 1, the tissue directly in contact with urine is the urothelium. This is an epithelium highly specialized regarding the watertight function and adaptation to large changes in urine volume. 
This distensible property is assumed by the pseudo-stratified character of the urothelium, while the water tightness is provided by the most differentiated urothelial cells known as umbrella cells. These cells are endowed with very tight junctions in the apicolateral side, while a well-organized protein barrier, called uroplakin plaque, covers the luminal surface [3,4]. The urothelium rest upon the lamina propria: an extracellular matrix which serves of nutritive and informative support for cells. The lamina propria is mostly made of collagen of type I and III $[5,6]$. Another type of extracellular matrix is found at the lower level. It contains three organized smooth muscle cells bundles responsible for urine emptying because of their contractile property. This extracellular matrix is characterized by the presence of an elastic fibres network which allows the distension of the bladder and a low pressure during filing.

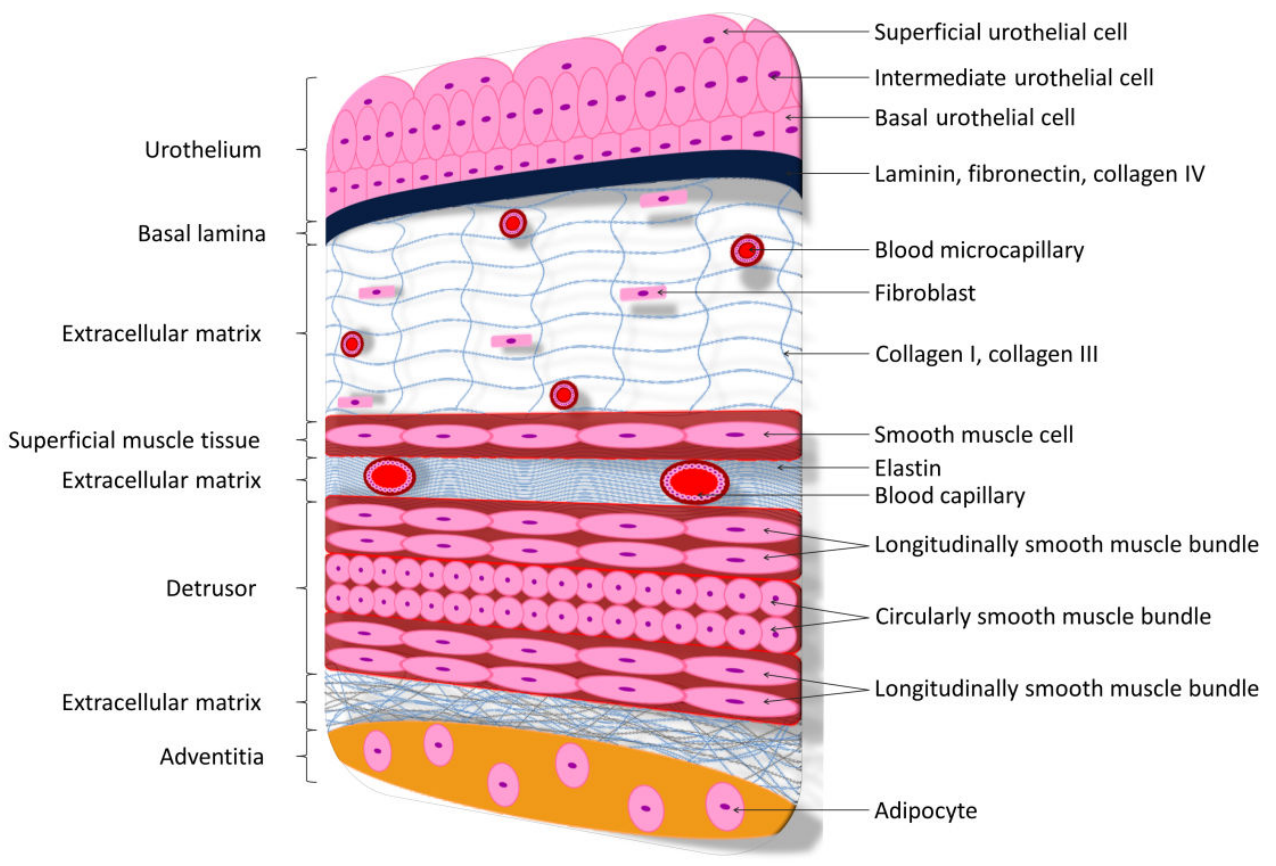

Figure 1. Scheme of bladder wall.

Every year 400 million person of all ages suffers from urinary disorders. Several congenital disorders such as bladder exstrophy or neurogenic bladder can affect the function of this organ. But there are also acquired bladder problems like traumatisms, inflammations, chronic interstitial cystitis and cancer which is the sixth most detected. All of these pathologies may require surgical augmentation or reconstruction of bladder wall to restore the storage capacity. The first application of a free tissue graft for bladder replacement was reported by Neuhof in 1917 [7], when fascia was used to augment bladders in dogs. Since that first report, diverse 
methods have been proposed for this type of surgical intervention, but actually the gold standard is the bladder replacement/repair with autologous segment of the gastrointestinal tract, also named Enterocystoplasty [8,9]. It has the advantage of being highly vascularized, promoting the survival of the graft. Unfortunately, this technique is associated with multiple short and long-term complications well documented (Table 1). The most frequent is metabolic disturbance, but mucus secretion, stone formation, bladder perforation and malignancy have also been found many years after enterocystoplasty [10-13]. These complications predominantly result from the difference between the absorption property of intestinal mucosa and the watertight function of the bladder epithelium, concerning the contact with urine.

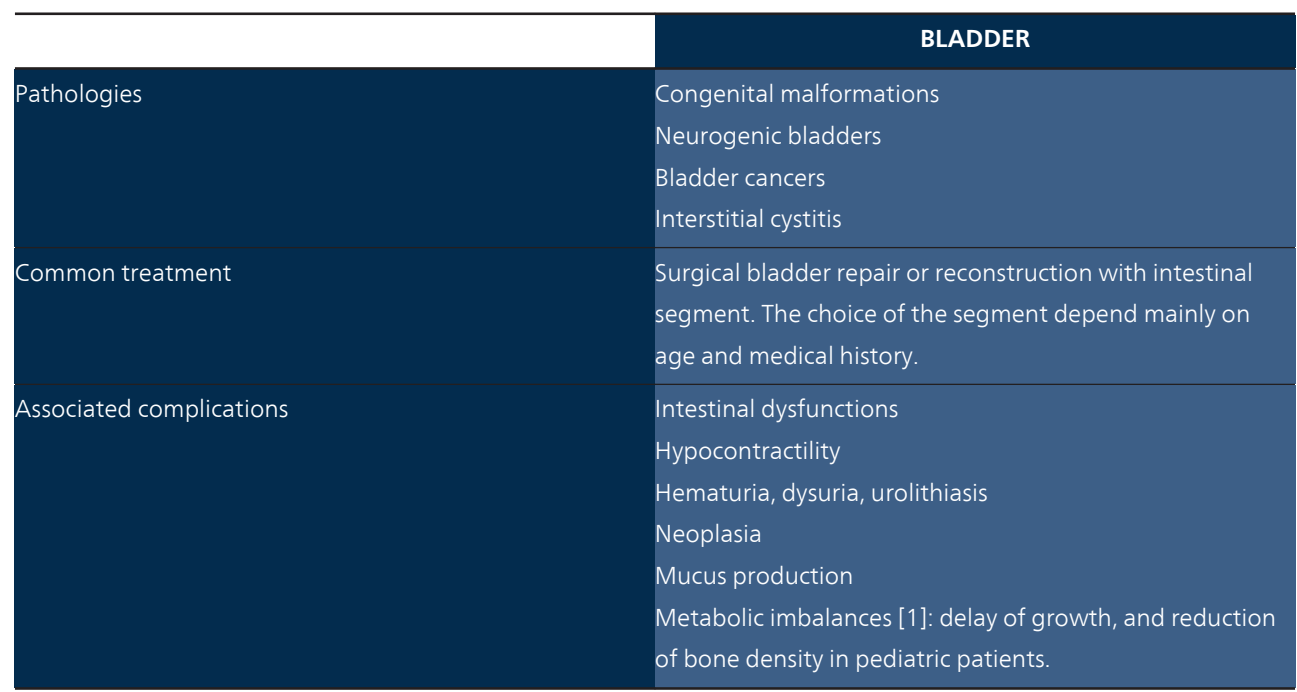

Table 1. Complications associated with current bladder treatment.

The lack of autologous tissue with similar properties to the native bladder is a limitation which led numerous research groups to develop alternative approaches. These last years, many fundamental knowledge concerning bladder cells and matrix have emerged, and have constituted an essential aid to the in vitro elaboration of various bladder models. This chapter will explain the different sources of cells used, the different type of engineered matrices, and the advanced concerning the techniques of in vitro culture. The emphasis will be placed on qualities and inconveniences of each approach, as well as the clinical potential of the engineered models.

\section{Cellular source}

Although the bladder is composed of many type of cells, the most harvested for vesical tissueengineering is urothelial and smooth muscle cells. Urothelial cells are organized into three 
layers which are anchored to the basal lamina. Basal cells, reside in the lower layer [14]. These progenitor cells develop themselves into intermediate cells, and differentiate into umbrella cells which are the most mature urothelial cells. The degree of urothelial differentiation is defined by the expression of specific proteins, such as keratins, claudins and uroplakins (Table 2) [15]. Smooth muscle cells have a fusiform shape and are assembled into bundles also organised into three layers. In the outer and inner layers, the smooth muscle bundles are oriented longitudinally, while those of the middle layer circularly. In each bundle, a single smooth muscle cell is innervated and action potential can propagated to neighboring cells in order to causes a coordinated contraction. The proliferation and differentiation of urothelial and smooth muscle cells are interdependent, because of factors released from these cells [16].

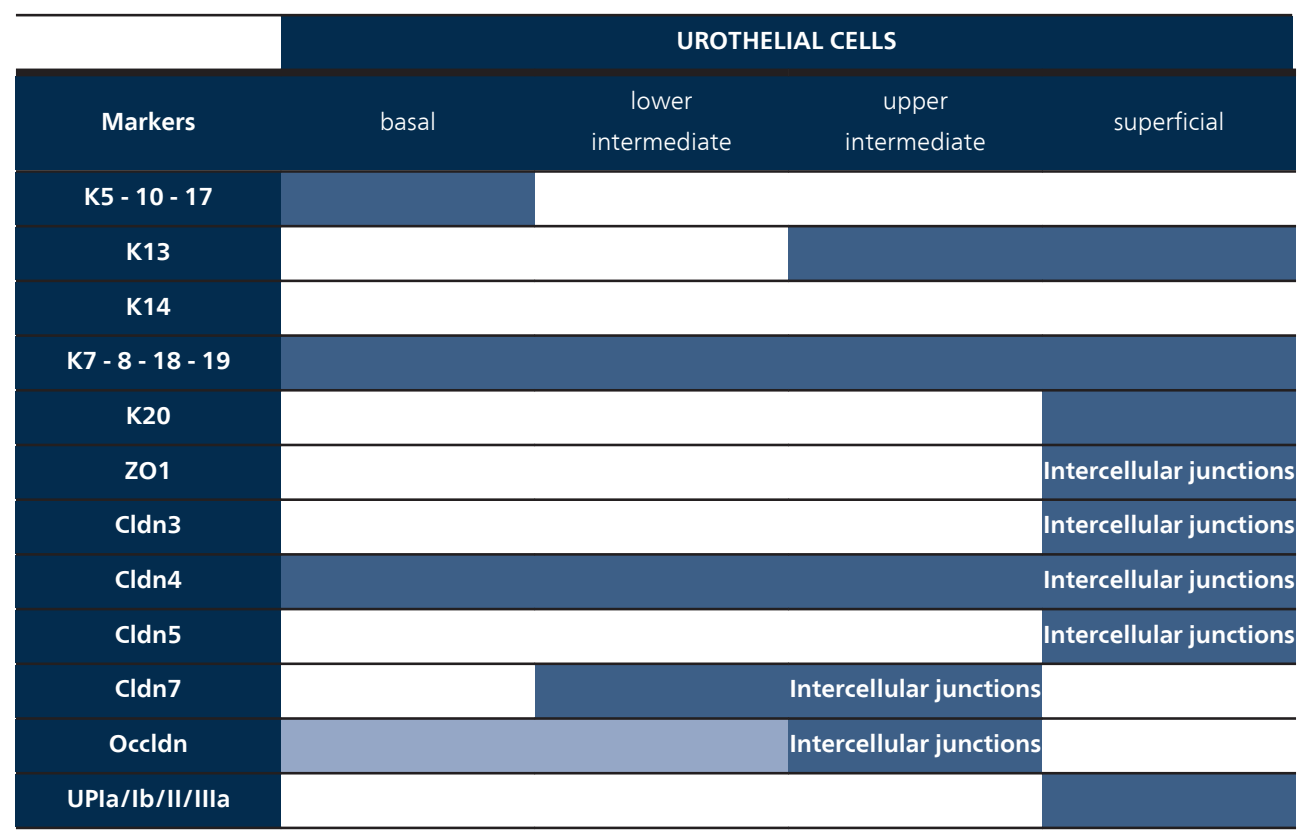

Table 2. Markers of urothelial cells (white $=$ no presence, light-blue = low presence, dark-blue $=$ strong presence) .

The importance to associate cells to a urological substitute was described by numerous studies [17-19]. These works showed that bladder substitute seeded with cells led to better in vivo regeneration, than the use of scaffold only. Cells help the graft integration; this is why the latest bladder substitutes are generally constituted by a combination of scaffold and cells.

\subsection{Urological cells}

Urothelial cells culture dates back to more than 30 years [20], and two major methods are developed for their extraction. The most former method is the explant technique. It consists to put a fragment of biopsy in nutritive medium, and let cells to migrate. Then, sequential action 
of trypsin will permit to harvest different cells with distinct adhesion properties. The other way is the enzymatic technique which consists to detach the urothelium from basal lamina, undergoing matrix extracellular protease action (thermolysin, dispase, collagenase IV) [21, 22]. This last method is faster, led to a suitable yield and a good purity. Finally to obtain enough cells, an amplification stage must be engaged. Generally, epithelial medium is used and supplemented with serum or/and specific growth factor (e.g. epithelial growth factor).

Smooth muscle cells were first described in 1913. In the same manner of urothelial cells, the two approaches could be used for extraction [23]. In the case of enzymatic treatment, the collagenase will be used to digest the extracellular matrix, made of collagen I principally, to liberate these cells. In the amplification stage, it is important to know that the serum percentage could modify the phenotype (contractile or secretory) and the functional property (electrophysiological) of these cells [24-26].

Endothelial cells are more and more frequently extracted and used for bladder reconstruction. Indeed, after transplantation the graft need to be rapidly vascularized to survive in vivo. Endothelial cells could organize themselves into capillary or secrete angiogenic factors which could improve a certain inosculation between the substitute and the host vasculature [27]. Some teams harvest endothelial cells from human umbilical vein (HUVEC), what asks ethical question, and other achieve these cells extraction from bladder microcapillaries which appeared more physiological for the elaboration of the vesical substitute. In this last case, enzymatic treatment could be used and the harvested cells must be purified with beads coupled with a specific endothelial marker (e.g. PECAM-1) [21].

\subsection{Stem cells}

In some situation the bladder is too affected and no healthy cells could be harvested to elaborate a tissue-engineering substitute. So, stem cells could represent a serious alternative and major avenue in the regenerative medicine. These cells are characterised by their capacity to maintain themselves by symmetrical division. But in a second phase, asymmetrical division occurs and leads to a daughter stem cell and a daughter differentiated cell. This last event makes difficult the in vitro preservation of stem cells and the constitution of an usable stock.

Embryonic stem cells are pluripotent and therefore can evolve into cells of all three embryonic layers (ectoderm, mesoderm and endoderm). The method of culture to enable specific differentiation pathways are not yet discovered, but the in vivo benefits have already been shown [28-29]. Unfortunately, their aptitudes to initiate teratoma, the need of genetic donorhost match to avoid immune-rejection and their potential illegal and non-ethical character compromise their clinical use.

Autologous stem cells could resolve these limitations. They present a low possibility of tumor malignancy and an exact histocompatibility. These cells niche within many adult tissues, in order to maintain homeostasis during tissue turnover and repair. However, they present lower proliferation capacity and plasticity which restricted their use.

Induced pluripotent stem cells appeared in 2006 and consist of reversion of differentiated cells into stem cells [30]. The reprogramming of adult cells requires the introduction of specific 
transcription factors (Oct4, Sox2, Klf4 and Myc), which allow to acquire differentiation potential comparable to the embryonic stem cells [31,32]. This ethical approach provides an easy and important cell sources for clinical application. However, even if a major risk of cancer has been corrected [33], epigenetic changes not yet entirely documented.

\section{Nature of scaffolds}

Once the cells have been obtained, they must be seeded onto a support (Table 3). The scaffolds are not only a physical support, but also supplier of biochemical information. It is difficult to encourage an appropriate in vitro cellular behaviour because spatial and temporal evolutions occurred during organogenesis. The complexity of extracellular matrix sequentially increases from morula to blastocyst stage [34, 35], and the signalisation between cells and extracellular matrix proteins change in a dynamic way [36]. In the present state of our knowledge, laminin is firstly synthetized to allow cellular adherence, while collagen IV and fibronectin appear more latter to initiate the cellular migration [37]. In a second phase, these extracellular matrix proteins form an organized matrix, the basal lamina, which is essential for the development of specialized tissue like epithelium [38]. Thus, tissue engineering must tend to create a controlled cellular microenvironment, taking into account the physiological process, to reach the experimental organogenesis goal. In another hand, scaffolds must offer comparable physical properties and have the capacity to confront the same mechanical strain. In the case of vesical repair, the substitute must combine resistance with elasticity to adapt itself to cyclic pressure caused by bladder filling and emptying. The scaffold biocompatibility is the starting point of material choice, and many products have been experimented with a clinical application point of view.

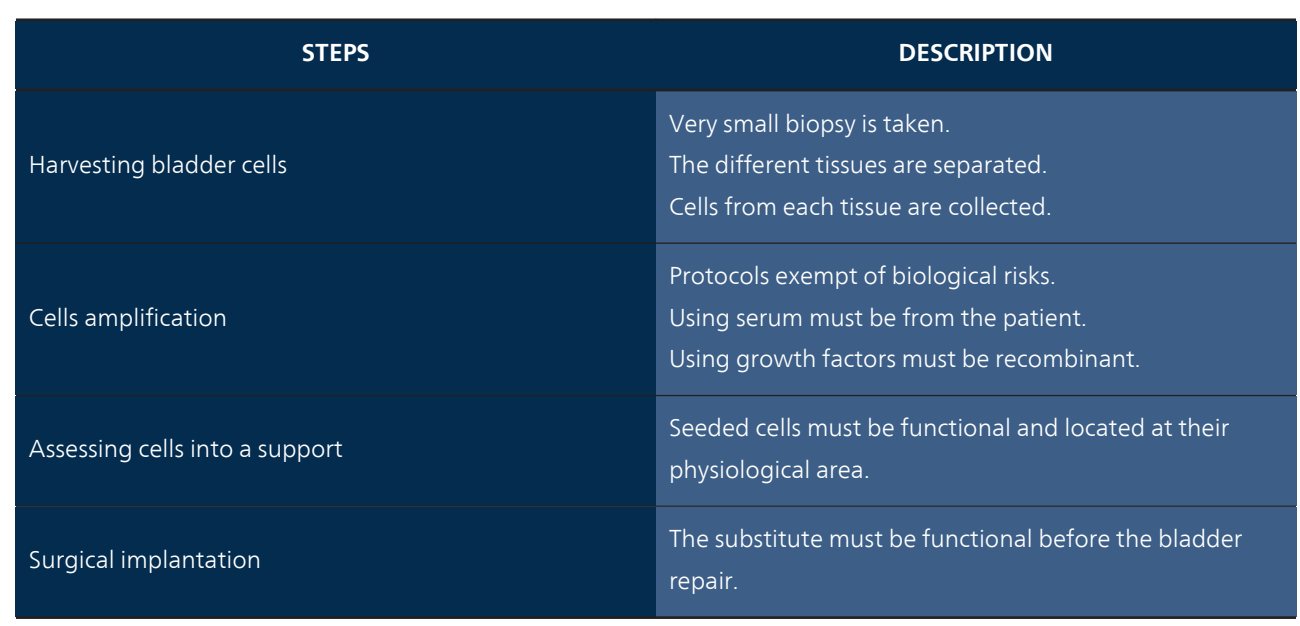

Table 3. General procedure in bladder reconstruction field. 


\subsection{Natural matrices}

Autologous tissues have been tested for bladder repair before the standard use of intestinal segment in the beginning of the eighties [1]. The skin, the omentum, the stomach, the pericardium have been used with very limited success [39-42]. Indeed, the epithelium of these tissues is not specialized in watertight function. So, the direct contact between the non-urological tissues and the toxic urine leads mainly to the formation of fibrosis and the contraction of the graft $[43,44]$.

Acellular tissue matrices represent a growing interest in the urological regenerative medicine. They are prepared from native tissue with a decellularisation and sterilisation process [45]. The purpose is to abolish immunological potential by discarding cells with physical, enzymatic or chemical protocols [46]. This materials offer the advantages of mechanical and biochemical environment ideal for the cellular recognition. Their matrix architecture is relatively preserved and the physiological organization of extracellular proteins can generate appropriate signalling to induce a suitable cellular behaviour [47]. Unfortunately, the decellularisation and sterilisation protocols include offensive biophysical and biochemical elements (temperature, $\mathrm{pH}$, ionic detergents) which can denature extracellular matrix proteins and damage the physiological environment [48]. Compared to other scaffolds, the ability to provide a nutritive supply by neovascularization after the graft, and therefore to promote the graft survival constitutes an attractive advantage which justifies the choice of acellular matrices $[49,50]$. Small intestinal submucosa (SIS) [51] and bladder acellular matrix graft (BAMG) [52, 53] are the most tested for bladder reconstruction in animal models. Microscopic analyses generally show a relative cellular organization, probably due to the presence of growth factors [54]. But functional tests such as watertightness or compliance are very seldom evaluated.

Concerning SIS, studies are conflicting. Some experiments describe the benefit to use SIS with contractility testing and immunostaining analysis [18], while other report fibrotic scarring observations and contraction during in vivo bladder augmentation in canine model [55]. Histologically, the urothelial and smooth muscle cells seeding led to a suitable adherence but without cellular maturation. This lack of regenerative potential could be caused by an absence of the appropriate extracellular proteins-cells communications, due to the fact that intestinal and bladder matrices are not similar [56]. It is known that extracellular matrix composition and structure presented by the bladder basal lamina have an impact on urothelial cells behaviour [57]. This is why bladder acellular matrix graft (BAMG) has been also tested. However, porcine bladder augmentation with a seeded BAMG demonstrated a local cells infiltration which remained limited in the periphery [58]. The insufficient cellular organization resulted in calcification process within the graft and its shrinkage. This incomplete cellular migration within the BAMG could be attributed to the decellularisation treatment, because it was reported that laminin and fibronectin are not preserved [59]. Thus, even if urological cells are placed into a familiar environment, the alteration of matrix proteins and the removal of intrinsic growth factors do not permit an optimal cellular signalisation [60]. Moreover, the disruption of the extracellular matrix compromises the specific architecture and leads to the loss of mechanicals properties, such as elasticity or resistance [61]. Optimization of these 
protocols is in progress and the damages caused by the preparation of decellularised tissue tend to be corrected $[62,63]$.

Intestinal segment and bladder wall are richly vascularized tissues, and this specificity is not negligible for the survival of the graft. However some parameters limit the clinical use of BAMG and SIS such as their xenogeneic origin and the associated risks of contamination by pathogens. Generally, the matrix proteins are highly conserved between the different species and seem to be non-immunogenic but an epitope, which is present in many species except human and a category of monkeys, was found in marketed SIS extracellular matrix [64]. Numerous postoperative inflammations have been reported [65] and in vitro DNA residues have been detected [66]. Because of their biological nature, the acellular tissues constitute a great potential for bladder reconstruction but the protocols of preparation must be improve to better preserve the extracellular matrix composition/architecture and to remove effectively any cellular fragments [67].

\subsection{Synthetic scaffolds}

Synthetic polymers are made of chemically assembled macromolecules and could have different physical properties (thermoplastics, thermo-hardenings and elastomers). The use of synthetic scaffolds, supported by the capacity to deliver any three-dimensional shape at lowprice, would allow to overcome the lack of native tissue available for transplantation. Each characteristic of this type of material can be controlled. The hydrolysis degradation of synthetic substitutes is important in the context of organ repair. The material used for bladder reconstruction must remain stable until the organization of seeded cells and the migration of surrounding cells. But during the terminal tissue remodelling, the substitute degradation must follow the tissue regeneration. The degradation rate of synthetic materials can be determinate by the molecular weight and the nature of biopolymer used for copolymerisation. Then the degraded fragments can be treated by the metabolic pathways [68-70]. The size of pores can also be modulated in order to influence the cellular migration, vascular invasion, and diffusion of nutrients, waste and oxygen [71, 72]. The cell adherence and growth can be enhanced by synthetic support, as shown for the reconstruction of different damaged tissues [73]. But in the case of bladder substitute, the in vitro evolution of seeded urologic cells into a mature cellular tissue has not yet demonstrated. There are fundamental differences between synthetic and biological molecules. The size range of fibers, their biophysical and biochemical properties are not comparable, and the challenge for these supports is to enhance a suitable interaction between cells and synthetic microenvironment, in spite of the dissimilarities existing with the physiological context.

Silicone, polyvinyl sponge and teflon, have been firstly tested for bladder reconstruction with the help of synthetic materials [74-78]. The advantage was to construct neobladders in a reproducible way, but the poor cytocompatibility, the lack of vascularization and their immunological potential led to significant complications. Because of the absence of cellular development, and urothelial cells particularly, the direct contact with urine caused the formation of fibrosis and contraction of the alloplastic graft. 
The more recent synthetic polymers including poly(ethylene glycol) (PEG), poly l-lactic acid (PLLA), poly(lactic-co- glycolic acid) (PLGA), poly( $\varepsilon$-caprolactone) (PCL), and polyurethane (PU), are used to pursue the bladder tissue-engineering research [79]. Few successes have been reported, but like in the case of acellular tissue matrices, it has been shown that the cell seeding play an important role concerning the graft integration [19]. This experience of canine bladder reconstruction have been led at mid-term with PGA scaffold coated with PLGA, and contrarily to the seeded synthetic substitute, contracture and inflammatory response have been observed with free scaffold one month post-transplantation. In spite of association of urothelial cells with a high proliferative capacity when urothelium is damaged [80], the surrounding cells of the host do not migrate in the whole surface of tissue-engineered bladder. The only one microscopic result demonstrated a well development of an urothelial tissue onto the seeded scaffold, with the presence of muscle bundles, but no analysis was led to assess the degree of urothelial maturation or the contractility function of smooth muscle cells. The potential of synthetic materials to support urothelial differentiation have not been proven yet. The same team have combined collagen with their PGA scaffold to lead bladder augmentation in patients with end-stage bladder disease [81]. The strategy is to supply a three-dimensional shape and mechanical resistance with the help of PGA, and to induce a cellular signal with the help of the collagen. It was shown that the biological activity provided by collagen improve the cellular propagation and development of seeded urothelial and smooth muscle cells. Additionally, omentum was used as a vascularization bed to support the graft survival [82]. Even if significant improvement of vesical capacity has been shown for only one of the seven patients, great strategic progresses have been made to initiate the elaboration of a composite scaffold able to communicate with cells and enhance their appropriate and terminal development. The scale of cellular environment and signalisation induced by specific protein sequences have been taking into account with the advent of biotechnologies.

\subsection{Nanobiotechnologies}

The nanotechnologies, which emerged in the last decade of the twentieth century, are defined by specific functions induced by the nanoscale dimension or the nanoscale organization of a material [83]. This characteristic could permit to overcome the problems encountered with the classic synthetic substitutes made of micrometer scale elements. The interest to include nanometer elements in the composition of synthetic scaffolds is to reproduce the scale of the size of native extracellular matrix proteins, and better manage cellular behaviour [84]. Recent researches demonstrated the effect of roughness surface, comparable with the roughness of the native bladder, on smooth muscle cells adhesion and urothelial cells development [85-87]. On another hand, the surface of synthetic materials could be modified with different chemistry, topography or roughness parameters, to improve the interaction with proteins. Thus, extracellular matrix proteins could be added to the scaffold in order to enhance the cellular interaction and to tend toward natural signalisation. Recent publication reported that vitronectin adsorption is improved by $20 \%$ if the roughness of synthetic surface is augmented with nanotechnology process, compared to nanosmooth surface [88]. A concrete example is illustrated by the increase of fibronectin adsorption onto synthetic material, because of the 
augmentation of roughness surface by adding carbon nanotubes and without changing the chemical properties.

Smooth muscle cells phenotype is affected by the nanometer topography of synthetic surfaces. This phenomenon was illustrated by recent works. One of them reported the elaboration of PLGA/PU materials with different feature dimensions. It is appeared that more the features size is comparable to the nanometer scale, like the extracellular matrix proteins, more the adhesion of bladder smooth muscle cells is improved [85]. A new chemically etching technique, which breaks ester and ether bonds via $\mathrm{NaOH}$ and $\mathrm{HNO} 3$ treatments, was tested by the same team to convert synthetic surface from micrometer to nanometer scale [89]. It was shown that this chemical treatment can generate nanoscale features on various synthetic surfaces (PLGA, PCL, PU), and then enhances the functions of bladder smooth muscle cells, compared to the conventional nanosmooth polymers. It is noted that micron, submicron and nanostructured polymers was generated with this same chemical protocol, and the development of bladder smooth muscle cells have been improved on the nanostructured surface, independently of a chemical action. So, any type of synthetic scaffold could be nano-engineered and promote bladder smooth muscle cell functions, such as elastin and collagen secretion [86]. Further studies demonstrated that the direct action of nanometer and submicron scale surface features is to promote the adsorption of proteins from serum present in culture media. Therefore it seems that the bladder smooth muscle cells behaviour is more directly improved by this serum proteins coating rather than the synthetic nanostructured environment [90,91]. These observations lead us to believe that the next generation of synthetic substitute could be grafted with soluble proteins in order to ameliorate the cellular signalisation.

Urothelial cells growth is also affected by the roughness of synthetic surfaces [87]. With nanometer rough synthetic surface, results show the improvement of adhesion and proliferation of urothelial cells, and also the reduction of calcium stones, often noticed with conventional synthetic materials. In vivo studies were performed in rodent model and confirmed the benefits showed with bladder smooth muscle cells. But nanostructured synthetic scaffold did not resist the contact with urine, leading to post-graft bladder leaks [92]. Further optimizations must be proposed to induce cellular differentiation. Fibronectin is recognized to induce cell migration, laminin for its adherence potential, therefore synthetic scaffolds will be completed with bioactive nano-elements. Protein sequences implicated in cellular signalisation will be used such as RGD peptide, a cell adhesive integrin-binding peptide found in most of extracellular matrix protein [93]. The development and maturation of seeded cells must be evaluated at longer term, while in vivo testing will occurred throughout animal models more comparable to human (the porcine urologic system is the nearest of human [94]).

\section{The self-assembly method}

The natural and synthetic materials have their own characteristics (Table 4), specific bioactive elements for the first and processing reproducibility for the second. The advances deserve a particular attention even if these experimental scaffolds could not be recommended at that 
time for clinical application. Acellular matrices present the risk of incomplete decellularisation and variability of biological activity. While synthetic materials are too far from the composition and architecture of physiological extracellular matrix. But one of the common disadvantages of these two models is the possibility of immunological response in vivo and therefore a graft rejection.

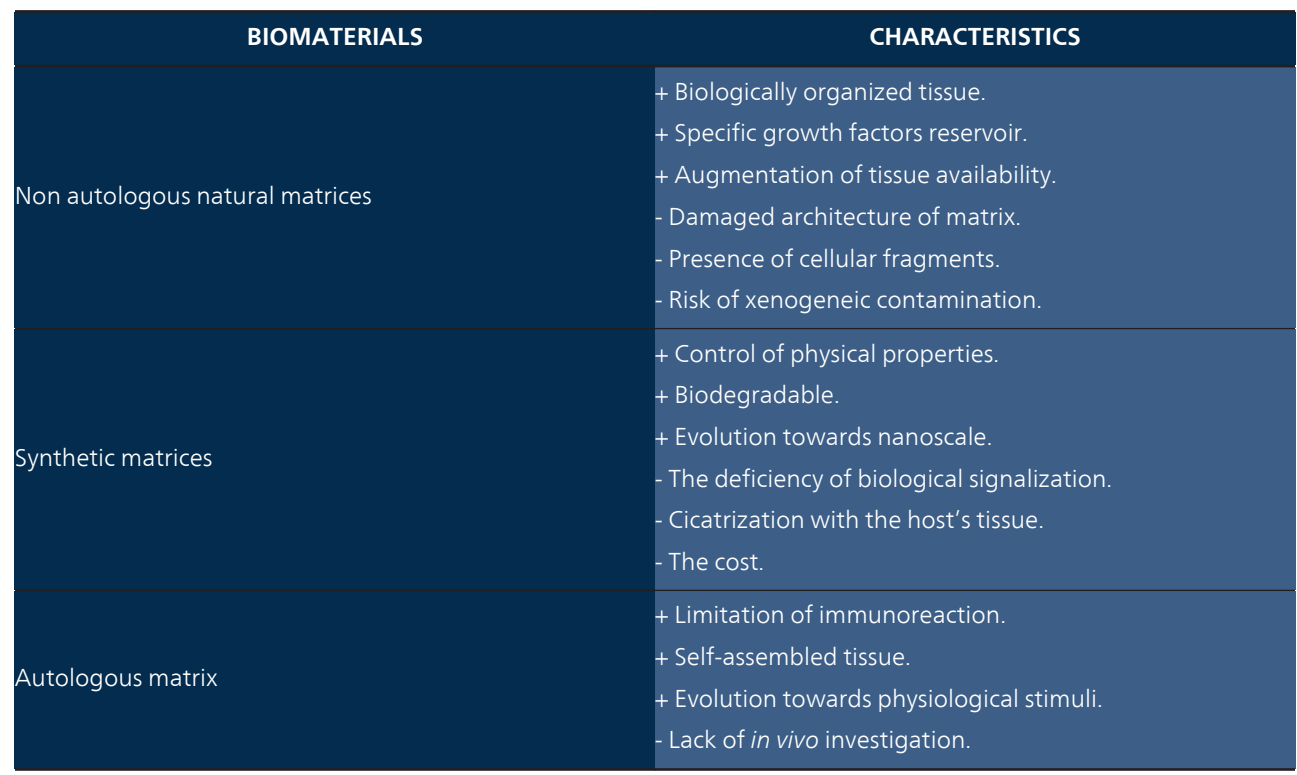

Table 4. Types of engineered bladder substitute.

Autologous and functional substitute represents the ideal alternative to avoid immunosuppressive therapy and to enhance the in vivo regeneration. The tissue-engineering field proposes a new approach to attain these objectives: the self-assembly method [95]. This technique is based on the use of the own cells of patient and their capacity to differentiate in vitro in order to form a mature tissue. At the Laboratoire d'organogénèse expérimentale (LOEX) many autologous substitutes are elaborated with controlled culture conditions and without the help of exogenous biomaterials. Human cornea [96], psoriatic skin model [97], microvascularized tissue-engineered skin substitute [98] has been developed for clinical repair or pharmacological investigations. Based on this method, an autologous vesical tissue was elaborated with a view to future clinical bladder repair/augmentation.

\subsection{Autologous vesical substitute}

A minimally invasive preoperative technique was developed to extract the bladder cells from the same small biopsy. Enzymatic method allows the harvesting of bladder cells with high purity [21]. Fibroblast, urothelial, endothelial and smooth muscle cells can be grown in the 
laboratory setting. Appropriate growth factors (e.g. epidermal growth factor for urothelial proliferation or vascular endothelial growth factor for endothelial cells) permit a good cellular expansion and the constitution of sufficient cellular bank.

The preparation of engineered vesical tissue begins with the elaboration of matrix support [99]. In presence of ascorbic acid [100,101], fibroblasts have the ability to synthesize and assemble their own collagen fibers, and form an extracellular matrix layer which could be manipulated. The autologous matrix layers are superimposed to provide a sufficient mechanical resistance and to create a three-dimensional biological environment. It is known that mesenchymalepithelial interactions play critical role in tissue development [102-105]. In the urological tract, mesenchyme regulates epithelial maturation and functional activities, while epithelium also contributes to the mesenchymal cells differentiation [106]. This is why the self-assembled scaffold is made of a specifically organized extracellular matrix where cells can develop themselves with appropriate biological signalling. Urothelial cells are seeded on the top of fused matrix layers and cultivated until they have proliferated on the whole surface, then we induced epithelial maturation with the use of the culture at air/liquid interface (Figure 2).
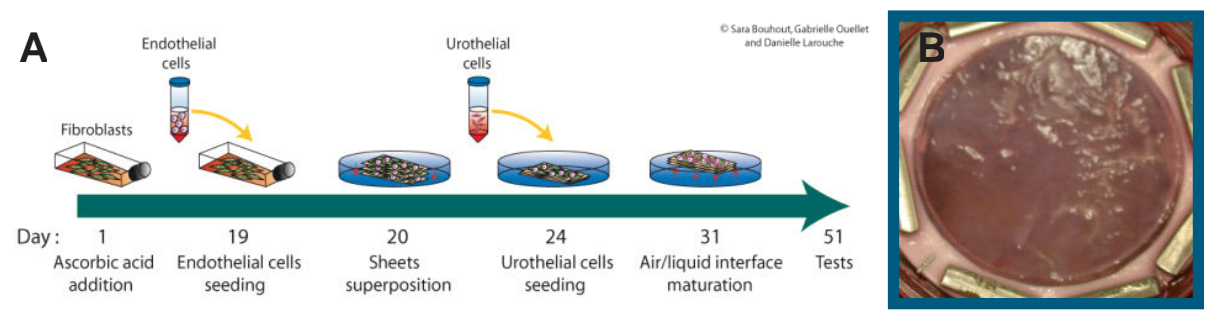

Figure 2. The self-assembly method (A) used to elaborate the engineered bladder tissue (B).

Masson's trichrome staining displayed a homogenous distribution of collagen I and the covering of stratified urothelium was roughly similar to a native vesical mucosa. Cytokeratin 8/18 staining confirmed the well widespread of a stratified urothelium, and claudine- 4 staining demonstrated the presence of tight junctions which are important to avoid urine infiltration. More interestingly, the permeability evaluation at urea was performed on the reconstructed vesical tissues and their watertightness profile is comparable to the native bladder. Conversely, the permeability test realized on self-assembled matrix, devoid of reconstructed urothelium, showed a fast diffusion of urea. This result supports the necessity to have a mature urothelium, in order to avoid urine extravasation, followed by in vivo necrosis and fibrosis of tissues. An attention was paid to the endothelialization of the substitute in order to encourage the postgraft survival. LOEX laboratory obtained a rapid inosculation between a capillary-like network of reconstructed skin and the host vasculature [6]. Thus endothelial cells, harvested from bladder microcapillaries, can be added before the seeding of urothelial cells, and cultured in order to form microcapillary-like network within the self-assembled substitute. The endothelialized vesical substitute displayed an also good watertightness profile than the native bladder, and mechanical properties were acceptable to allow suturing. The potential limit of 
this method is the incertitude to dispose of healthy bladder cells, especially in a case of endstage disease. This is why the question concerning the getting of an appropriate source of cells remains in reflection, but in some case, urological cells could be harvested from upper segment of urethra because of its sharing of the same embryologic origin with the bladder [107]. The self-assembled vesical model still must to be completed and tested in vivo, but its autologous character and its efficiency as a barrier to urea are essential properties to tend toward an ideal substitute for bladder augmentation.

\subsection{Culture conditions}

In regenerative medicine domain, the goal of tissue engineering is to deliver a functional substitute. It consists in obtaining specific cells with sufficient purity and quantity, and inducing their differentiation in order to ensure their biological role. Self-assembled extracellular matrix provides both a physical and informative support for urological cells, but the control of cellular proliferation/differentiation balance deserve to be better taking into account. Several studies reported an altered maturation of urothelial cells in vitro, particularly a defect of uroplakins synthesis [108] and their incomplete assembly at the apical surface of urothelial cells $[109,110]$. The pathway of differentiation is induced by defined intracellular signals. Transcription factors such as Fox-A1, PPAR $\gamma$ and RXR, have been identified as being involved in the expression of proteins implicated in the urothelial functions [111]. The bladder is subjected to different pressure during the emptying/filling cycle, and the cells are constantly exposed to mechanical stresses (e.g. hydrodynamic strength) [112]. It was shown that mechanical stress acts on survival, migration and proliferation of bladder cells [113-115]. More accurately, cyclic hydrostatic pressure seems to promote uroplakin trafficking/maturation [116-118], and to influence the growth of bladder smooth muscle cells by activating Rac1 signaling pathway [119], or their proliferation via the PI3K activation [120]. Even if the molecular mechanism acting under cyclic pressure remains not elucidated, the conviction that physiological stimulations would be required for the differentiation of bladder cells cultured in vitro is more and more evocated in the literature [121-123].

In the beginning, mechanical stimuli were included in cellular culture protocols and interactions between cells or between cells and extracellular matrix proteins were analyzed [124, 125], but physiological conditions were not yet investigated. In 2008, the mimic of bladder filling and emptying was tested through a bioreactor which applies hydrostatic pressure waves in a cyclic way [126]. Porcine BAMG was used and the expression of extracellular matrix proteins was more elevated under dynamic condition. This result is encouraging for acellular matrix application. Indeed, acellularisation treatment deteriorates the matrix architecture and the obtained tissue after treatment had a too high porosity [127]. Because of its property to support cell proliferation and migration, hyaluronic acid could be used in static regime to decrease the porosity observed after the acellularisation process [128], but this step could be replaced by placing the reconstructed substitute under physical stress. The urothelial cells were also influenced since mechanical stimulations induced the increasing of uroplakin II expression. The effects of physical strain must be studied in more details because gene expression does not constitute sufficient information, since the protein functionality depends on its 
complete synthesis, its good folding and its appropriate localization. But these preliminary results encourage the integration of mechanical phase in the process of engineered bladder. This is why we designed a bioreactor which is scheduled to reproduce the physiological intravesical pressures at the fetal stage, and replace the air/liquid phase used for our selfassembled model. Briefly, our self-assembled vesical tissue is placed between two chambers, with urothelial side face to the pressure chamber. To mimic the low pressure maintained during filling phase, $5 \mathrm{~cm} \mathrm{H} 2 \mathrm{O}$ is applied during few hours. In the last hour the pressure slowly increase until $15 \mathrm{~cm} \mathrm{H} 2 \mathrm{O}$, and then decline quickly to zero in a few seconds in order to simulate the voiding and complete the urination cycle. Compared to static condition, short-term dynamic culture significantly improves the urothelial development and the watertightness profile of the self-assembled substitute [129]. These results are in conformity with outcomes related in our dynamical engineered urethra which displayed an increase of uroplakins immunostaining at urothelial cells surface [130]. Whatever the substitute model, the mechanical stimulations must take more importance within protocols of in vitro bladder reconstruction. When must the dynamic phase intervene? How long time must it intervene? Should the pressure cycle follow a constant scheme or must it evolved during the process? Better understanding of bladder cells mechanotransduction may ameliorate the setting up of a dynamical environment appropriate to the reconstruction of a mature and functional vesical tissue.

\section{Conclusion}

Bladder exposition to diverse pathologies could jeopardize its function of elastic and watertight reservoir. To date, the clinical technique for bladder repair is associated to a high level of morbidity. Based on the well documented post-operative complications, it is appear that the ideal bladder substitute must combine the compliance conferred by the nature and architecture of the matrix support, with a urinary barrier provided by the differentiation degree of urothelium. Natural and synthetic scaffolds were investigated to reproduce the bladder abilities and some successes were furthered the urological tissue-engineering domain. But due to their poor mechanical stability, immune responses, and incomplete cellular maturation, these models remain insufficiently developed to be used in clinical application. At present, teams which support the acellularised or polymeric substitute are working on the next generation of engineered bladder model. For example, nanodimensional surface features would be included in order to imitate the nanometer topography of native tissue, and therefore, to enhance interactions between bladder cells and the proposed environment. Among all biotechnologies, the self-assembly method proves to be a promising approach to elaborate a vesical substitute comparable to the structure and function of native tissue. The good watertightness of reconstructed mucosa and its autologous character will permit a suitable integration in vivo, and promote the cellular expansion. The application of appropriate culture method, such as dynamical regime, will lead to the maturation of the reconstructed connective tissue and its urothelium. The capacity of the self-assembled tissue to be pre-endothelialized might avoid the necrosis of the graft attributed to the lack of synchronized neovascularization. Another aspect which is rarely taking into account is the capacity for a graft to growth with 
pediatric patient. The self-assembled tissue is made of autologous cells only, and constitutes a serious alternative in the urological tissue-engineering field. Research continues its efforts to optimize the different reconstructed substitutes, and agree the necessity to evaluate them at long-term through bladder with specific dysfunctions.

\section{Acknowledgements}

The authors thank Kenza Bouhout for her useful discussions and her participation in the illustration of this chapter.

\section{Author details}

Sara Bouhout ${ }^{1}$, Alexandre Rousseau ${ }^{1}$, Stéphane Chabaud ${ }^{1}$, Amélie Morissette $^{1}$ and Stéphane Bolduc ${ }^{1,2}$

1 Laboratoire d'Organogenèse Expérimentale/LOEX, Centre de recherche FRQS du CHA universitaire de Québec, Medicine Faculty, Laval University, Quebec City, Canada

2 Department of Urology, CHUQ, Laval University, Quebec City, Quebec, Canada

\section{References}

[1] Tariel, E. Mongiat Artus P., Meria P., Cortesse A., Desgrandchamps F., Teillac P. Replacement enterocystoplasty in man (except Hautmann): principles and technical considerations. Ann Urol. (Paris) (2006). , 40(6), 368-94.

[2] Apodaca, G. The uroepithelium: not just a passive barrier. Traffic (2004). , 117-128.

[3] Born, M, Pahner, I, Ahnert-hilger, G, \& Jöns, T. The maintenance of the permeability barrier of bladder facet cells requires a continuous fusion of discoid vesicles with the apical plasma membrane. Eur J Cell Biol. (2003). , 82(7), 343-50.

[4] Liang, F. X, Riedel, I, Deng, F. M, Zhou, G, Xu, C, Wu, X. R, Kong, X. P, Moll, R, \& Sun, T. T. Organization of uroplakin subunits: transmembrane topology, pair formation and plaque composition. Biochem J. (2001). Pt 1): 13-18.

[5] Young, D. M, Greulich, K. M, \& Weier, H. G. Species-specific in situ hybridization with fluorochrome-labeled DNA probes to study vascularization of human skin grafts on athymic mice. J Burn Care Rehabil. (1996). , 305-310. 
[6] Tremblay, P. L, Hudon, V, Berthod, F, Germain, L, \& Auger, F. A. Inosculation of tissue-engineered capillaries with the host's vasculature in a reconstructed skin transplanted on mice. Am J Transplant. (2005). , 5(5), 1002-10.

[7] Neuhof, H. Fascial transplantation into visceral defects: an experimental and clinical study. Surg Gynecol and Obst. (1917). , 25, 383-387.

[8] Gearhart, J. P, Albertsen, P. C, Marshall, F. F, \& Jeffs, R. D. Pediatric applications of augmentation cystoplasty: the Johns Hopkins experience. J Urol. (1986). , 430-432.

[9] Quek, ML, \& Ginsberg, . . Long-term urodynamics followup of bladder augmentation for neurogenic bladder. J Urol. 2003; 169(1): p. 195-8.

[10] Mundy, A. R, \& Nurse, D. E. Calcium balance, growth and skeletal mineralisation in patients with cystoplasties. Br J Urol. (1992). , 69(3), 257-9.

[11] Mcdougal, W. S. Metabolic complications of urinary intestinal diversion. J Urol. (1992). , 147(5), 1199-208.

[12] Woodhams, S. D, Greenwell, T. J, Smalley, T, \& Mundy, A. R. Factors causing variation in urinary N-nitrosamine levels in enterocystoplasties. BJU Int. (2001). , 88(3), 187-91.

[13] Ali-el-dein, B, Tabey, N, Abdel-latif, M, Abdel-rahim, M, \& Bahnasawy, M. S. Late uro-ileal cancer after incorporation of ileum into the urinary tract. J Urol. (2002). , 167(1), 84-8.

[14] Bolland, F, \& Southgate, J. Bio-engineering urothelial cells for bladder tissue transplant. Expert Opin Biol Ther. (2008).

[15] Veranic, P, Romih, R, \& Jezernik, K. What determines differentiation of urothelial umbrella cells? Eur J Cell Biol. (2004). , 83(1), 27-34.

[16] Liu, W, Li, Y, Hayward, S, Cunha, G, \& Baskin, L. Diffusable growth factors induce bladder smooth muscle differentiation. In Vitro Cell Dev Biol Anim. (2000). , 36(7), 476-84.

[17] Cheng, E. Y, \& Kropp, B. P. Urologic tissue engineering with smallintestinal submucosa : potential clinical applications. World J. Urol. (2000). , 18, 26-30.

[18] Kropp, B. P, Sawyer, B. D, Shannon, H. E, Rippy, M. K, Badylak, S. F, Adams, M. C, Keating, M. A, Rink, R. C, \& Thor, K. B. Characterization of small intestinal submucosa regenerated canine detrusor: assessment of reinnervation, in vitro compliance and contractility. J. Urol. (1996). , 156, 599-607.

[19] Oberpenning, F, Meng, J, Yoo, J. J, \& Atala, A. De novo reconstitution of a functional mammalian urinary bladder by tissue engineering. Nat. Biotechnol. (1999). , 17, 149-155. 
[20] Elliott, A. Y, Stein, N, \& Fraley, E. E. Technique for cultivation of transitional epithelium from mammalian urinary bladder. In Vitro. (1975). , 11(5), 251-4.

[21] Magnan, M, Berthod, F, Champigny, M. F, Soucy, F, \& Bolduc, S. In vitro reconstruction of a tissue-engineered endothelialized bladder from a single porcine biopsy. J Pediatr Urol. (2006). , 2(4), 261-70.

[22] Turner, A. M, Subramaniam, R, Thomas, D. F, \& Southgate, J. Generation of a functional, differentiated porcine urothelial tissue in vitro. Eur Urol. (2008). , 54(6), 1423-32.

[23] Ma, F. H, Higashira, H, Ukai, Y, Hanai, T, Kiwamoto, H, Park, Y. C, \& Kurita, T. A new enzymic method for the isolation and culture of human bladder body smooth muscle cells. Neurourol. Urodyn. (2002). , 21, 71-79.

[24] Chambers, P, Neal, D. E, \& Gillespie, J. I. Ca2+ signalling in cultured smooth muscle cells from human bladder. Exp. Physiol. (1996). , 81, 553-564.

[25] (Champi C. Quelques résultats de la méthode de culture de tissus. I. Généralités. II. Le muscle lisse. Arch. Zool. Exp. Gen. 1913-1914; 53: 42-51). 53, 42-51.

[26] Probst, M, Dahiya, R, Carrier, S, \& Tanagho, E. A. Reproduction of functional smooth muscle tissue and partial bladder replacement. Br. J. Urol. (1997). , 79, 505-515.

[27] Young, D. M, Greulich, K. M, \& Weier, H. G. Species specific in situ hybridization with fluorochrome-labeled DNA probes to study vascularization of human skin grafts on athymic mice. J Burn Care Rehabil (1996).

[28] Lamba, D. A, Gust, J, \& Reh, T. A. Transplantation of human embryonic stem cellderived photoreceptors restores some visual function in Crx-deficient mice. Cell Stem Cell. (2009). , 4, 73-9.

[29] Yang, D, Zhang, Z. J, Oldenburg, M, Ayala, M, \& Zhang, S. C. Human embryonic stem cell-derived dopaminergic neurons reverse functional defi cit in parkinsonian rats. Stem Cells. (2008). , 26, 55-63.

[30] Takahashi, K, \& Yamanaka, S. Induction of pluripotent stem cells from mouse embryonic and adult fibroblast cultures by defined factors. Cell. (2006). , 126, 663-76.

[31] Chin, M. H, Mason, M. J, Xie, W, Volinia, S, Singer, M, Peterson, C, Ambartsumyan, G, Aimiuwu, O, Richter, L, Zhang, J, Khvorostov, I, Ott, V, Grunstein, M, Lavon, N, Benvenisty, N, Croce, C. M, Clark, A. T, Baxter, T, Pyle, A. D, Teitell, M. A, Pelegrini, M, Plath, K, \& Lowry, W. E. Induced pluripotent stem cells and embryonic stem cells are distinguished by gene expression signatures. Cell Stem Cell. (2009). , 5, 111-23.

[32] Yu, J, Vodyanik, M. A, Smuga-otto, K, Antosiewicz-bourget, J, Frane, J. L, Tian, S, Nie, J, Jonsdottir, G. A, Ruotti, V, Stewart, R, Slukvin, I. I, \& Thomson, J. A. Induced pluripotent stem cell lines derived from human somatic cells. Science. (2007). , 318, 1917-20. 
[33] Nakagawa, M, Koyanagi, M, Tanabe, K, Takahashi, K, Ichisaka, T, Aoi, T, Okita, K, Mochiduki, Y, Takizawa, N, \& Yamanaka, S. Generation of induced pluripotent stem cells without Myc from mouse and human fibroblasts. Nat Biotechnol. (2008). , 26(1), 101-6.

[34] Thompson, D. W, \& Bonner, J. T. On Growth and Form; Cambridge University Press (New York). (1952).

[35] Ingber, D. E. Mechanical control of tissue morphogenesis during embryological development. Int. J. Dev. Biol. (2006). , 50, 255-266.

[36] Nelson, C. M, \& Bissell, M. J. Of extracellular matrix, scaffolds, and signaling: tissue architecture regulates development, homeostasis, and cancer. Annu. Rev. Cell Dev. Biol. (2006). , 22, 287-309.

[37] Leivo, I. Structure and composition of early basement membranes: studies with early embryos and teratocarcinoma cells. Med. Biol. (1983). , 61, 1-30.

[38] Ekblom, P, Alitalo, K, Vaheri, A, Timpl, R, \& Saxén, L. Induction of a basement membrane glycoprotein in embryonic kidney: possible role of laminin in morphogenesis. Proc Natl Acad Sci U S A. (1980). , 77(1), 485-9.

[39] Draper, J. W, \& Stark, R. B. End results in the replacement of mucous membrane of the urinary bladder with thick-split grafts of skin. Surgery. (1956). , 39(3), 434-40.

[40] Goldstein, M. B, Dearden, L. C, \& Gualtieri, V. Regeneration of subtotally cystectomized bladder patched with omentum: an experimental study in rabbits. J Urol. (1967). , 97(4), 664-8.

[41] Andretto, R, \& Gonzales, J. Guidugli Netro J., de Miranda JF., Antunes AM. Experimental cystoplasty in dogs using preserved equine pericardium. AMB Rev Assoc Med Bras. (1981). , 27(5), 153-4.

[42] Nguyen, D. H, \& Mitchell, M. E. Gastric bladder reconstruction. Urol Clin North Am. (1991). , 18(4), 649-57.

[43] Burbige, K. A, \& Hensle, T. W. The complications of urinary tract reconstruction. J Urol. (1986). Pt 2): 292-7.

[44] Vemulakonda, V. M, Lendvay, T. S, Shnorhavorian, M, Joyner, B. D, Kaplan, H, Mitchell, M. E, \& Grady, R. W. Metastatic adenocarcinoma after augmentation gastrocystoplasty. J Urol. (2008). , 179(3), 1094-6.

[45] Rosario, D. J, \& Reilly, G. C. Ali Salah E., Glover M., Bullock AJ., Macneil S. Decellularization and sterilization of porcine urinary bladder matrix for tissue engineering in the lower urinary tract. Regen Med. (2008). , 3(2), 145-56.

[46] Gilbert, T. W, Sellaro, T. L, \& Badylak, S. F. Decellularization of tissues and organs. Biomaterials. (2006). , 27, 3675-3683. 
[47] Sutherland, R. S, Baskin, L. S, Hayward, S. W, \& Cunha, G. R. Regeneration of bladder urothelium, smooth muscle, blood vessels and nerves into an acellular tissue matrix. J Urol. (1996). Pt 2): 571-7.

[48] Reing, J. E, Brown, B. N, Daly, K. A, Freund, J. M, Gilbert, T. W, Hsiong, S. X, Huber, A, Kullas, K. E, Tottey, S, Wolf, M. T, \& Badylak, S. F. The effects of processing methods upon mechanical and biologic properties of porcine dermal extracellular matrix scaffolds. Biomaterials. (2010). , 31(33), 8626-33.

[49] Lantz, G. C, Badylak, S. F, Hiles, M. C, Coffey, A. C, Geddes, L. A, Kokini, K, Sandusky, G. E, \& Morff, R. J. Small intestinal submucosa as a vascular graft: a review. J Invest Surg. (1993). , 6(3), 297-310.

[50] Kajbafzadeh, A. M, Payabvash, S, Salmasi, A. H, Sadeghi, Z, Elmi, A, Vejdani, K, Tavangar, S. M, Tajik, P, \& Mahjoub, F. Time-dependent neovasculogenesis and regeneration of different bladder wall components in the bladder acellular matrix graft in rats. J Surg Res. (2007). , 139(2), 189-202.

[51] Zhang, Y, Kropp, B. P, Moore, P, Cowan, R, \& Furness, P. D. rd, Kolligian ME., Frey P., Cheng EY. Coculture of bladder urothelial and smooth muscle cells on small intestinal submucosa: potential applications for tissue engineering technology. J Urol. (2000). , 164, 928-35.

[52] Dahms, S. E, Piechota, H. J, Dahiya, R, Lue, T. F, \& Tanagho, E. A. Composition and biomechanical properties of the bladder acellular matrix graft: comparative analysis in rat, pig and human. Br J Urol. (1998). , 82, 411-9.

[53] Bolland, F, Korossis, S, Wilshaw, S. P, Ingham, E, Fisher, J, Kearney, J. N, \& Southgate, J. Development and characterisation of a full-thickness acellular porcine bladder matrix for tissue engineering. Biomaterials. (2007). , 28, 1061-70.

[54] Hurst, R. E, \& Bonner, R. B. Mapping of the distribution of significant proteins and proteoglycans in small intestinal submucosa by fluorescence microscopy. J Biomater Sci Polym Ed. (2001). , 12(11), 1267-79.

[55] Zhang, Y, Frimberger, D, Cheng, E. Y, Lin, H. K, \& Kropp, B. P. Challenges in a larger bladder replacement with cell-seeded and unseeded small intestinal submucosa grafts in a subtotal cystectomy model. BJU Int. (2006). , 98(5), 1100-5.

[56] Sievert, K. D, \& Tanagho, E. A. Organ-specific acellular matrix for reconstruction of the urinary tract. World J Urol. (2000). , 18(1), 19-25.

[57] Erdani Kreft MSterle M. The effect of lamina propria on the growth and differentiation of urothelial cells in vitro. Pflugers Arch. (2000). Suppl): R, 181-2.

[58] Merguerian, P. A, Reddy, P. P, Barrieras, D. J, Wilson, G. J, Woodhouse, K, Bagli, D. J, Mclorie, G. A, \& Khoury, A. E. Acellular bladder matrix allografts in the regeneration of functional bladders: evaluation of large-segment $(>24 \mathrm{~cm})$ substitution in a porcine model. BJU Int. (2000). , 85(7), 894-8. 
[59] Farhat, W. A, Chen, J, Haig, J, Antoon, R, Litman, J, Sherman, C, Derwin, K, \& Yeger, $\mathrm{H}$. Porcine bladder acellular matrix (ACM): protein expression, mechanical properties. Biomed Mater (2008).

[60] Reing, J. E, Brown, B. N, Daly, K. A, Freund, J. M, Gilbert, T. W, Hsiong, S. X, Huber, A, Kullas, K. E, Tottey, S, Wolf, M. T, \& Badylak, S. F. The effects of processing methods upon mechanical and biologic properties of porcine dermal extracellular matrix scaffolds. Biomaterials. (2010). , 2010(31), 33-8626.

[61] Olde Damink LHDijkstra PJ., Van Luyn MJ., Van Wachem PB., Nieuwenhuis P., Feijen J. Influence of ethylene oxide gas treatment on the in vitro degradation behavior of dermal sheep collagen. J Biomed Mater Res. (1995). , 29(2), 149-55.

[62] Brown, B, Lindberg, K, Reing, J, Stolz, D. B, \& Badylak, S. F. The basement membrane component of biologic scaffolds derived from extracellular matrix. Tissue Eng. (2006). , 12(3), 519-26.

[63] Hodde, J. P, Record, R. D, Liang, H. A, \& Badylak, S. F. Vascular endothelial growth factor in porcine-derived extracellular matrix. Endothelium. (2001). , 8(1), 11-24.

[64] Badylak, S. F, \& Gilbert, T. W. Immune response to biologic scaffold materials. Semin Immunol. (2008). , 20(2), 109-16.

[65] Ho, K. L, Witte, M. N, \& Bird, E. T. ply small intestinal submucosa tension-free sling: Spectrum of postoperative inflammation. J Urol. (2004). , 171(1), 268-71.

[66] Feil, G, Christ-adler, M, Maurer, S, Corvin, S, Rennekampff, H. O, Krug, J, Hennenlotter, J, Kuehs, U, Stenzl, A, \& Sievert, K. D. Investigations of urothelial cells seeded on commercially available small intestine submucosa. Eur Urol. (2006). , 50(6), 1330-7.

[67] Kropp, B. P, Cheng, E. Y, Lin, H. K, \& Zhang, Y. Reliable and reproducible bladder regeneration using unseeded distal small intestinal submucosa. J Urol. (2004). Pt 2): 1710-3.

[68] Jeong, S. I, Kim, B. S, Lee, Y. M, Ihn, K. J, Kim, S. H, \& Kim, Y. H. Morphology of Elastic Poly(L-lactide-co-epsilon-caprolactone) Copolymers and in vitro and in vivo Degradation Behavior of their Scaffolds, Biomacromolecules. (2004). , 5, 1303-1309.

[69] Jeong, S. I, Kim, B. S, Kang, S. W, Kwon, J. H, Lee, Y. M, Kim, S. H, \& Kim, Y. H. In vivo Biocompatibilty and Degradation Behavior of Elastic Poly(L-lactideco-EpsilonCaprolactone) Scaffolds. Biomaterials. (2004). , 25, 5939-5946.

[70] Hayami, J. W, Surrao, D. C, Waldman, S. D, \& Amsden, B. G. Design and Characterization of a Biodegradable Composite Scaffold for Ligament Tissue Engineering. J Biomed Mater Res. (2010). A: , 1407-1420. 
[71] Salem, A. K, Stevens, R, Pearson, R. G, Davies, M. C, Tendler, S. J, Roberts, C. J, Williams, P. M, \& Shakesheff, K. M. Interactions of 3T3 Fibroblasts and Endothelial Cells with Defined Pore Features. J Biomed Mater Res. (2002). , 61, 212-217.

[72] Botchwey, E. A, Dupree, M. A, Pollack, S. R, Levine, E. M, \& Laurencin, C. T. (2003). Tissue Engineered Bone: Measurement of Nutrient Transport in Three-Dimensional Matrices. J Biomed Mater Res. 2003; 67A: , 357-367.

[73] Burdick, J. A, \& Vunjak-novakovic, G. Engineered Microenvironments for Controlled Stem Cell Differentiation. Tissue Eng. (2009). A: , 205-219.

[74] Kudish, H. G. The use of polyvinyl sponge for experimental cystoplasty. J Urol. (1957). , 78(3), 232-5.

[75] Bogash, M, Kohler, F. P, Scott, R. H, \& Murphy, J. J. Replacement of the urinary bladder by a plastic reservoir with mechanical valves. Surg Forum. (1960). , 10, 900-3.

[76] Kelâmi, A, Dustmann, H. O, Lüdtke-handjery, A, Cárcamo, V, \& Herlld, G. Experimental investigations of bladder regeneration using teflon-felt as a bladder wall substitute. J Urol. (1970). , 104(5), 693-8.

[77] Bona, A. V, \& De Gresti, A. Partial substitution of urinary bladder with teflon prothesis. Minerva Urology. (1966). , 18, 43-47.

[78] Rohrmann, D, Albrecht, D, Hannappel, J, Gerlach, R, Schwarzkopp, G, \& Lutzeyer, W. Alloplastic replacement of the urinary bladder. J. Urol. (1996). , 156(6), 2094-7.

[79] Wiesmann, H. P, \& Meyer, U. Biomaterials. In Meyer U., Meyer T., Handschel J., Wiesmann HP. eds. Fundamentals of Tissue Engineering and Regenerative Medicine. Springer-Verlag, Berlin Heidelberg, (2009). Chapt. , 34, 457-68.

[80] De Boer, W. I, Schuller, A. G, Vermey, M, \& Van Der Kwast, T. H. Expression of growth factors and receptors during specific phases in regenerating urothelium after acute injury in vivo. Am J Pathol. (1994). , 145(5), 1199-207.

[81] Atala, A, Bauer, S. B, Soker, S, Yoo, J. J, \& Retik, A. B. Tissue-engineered autologous bladders for patients needing cystoplasty. Lancet. (2006). , 367(9518), 1241-6.

[82] Turner, A. M, \& Subramanian, R. Thomas DFM., Southgate J. Bladder tissue engineering. In Boccaccini A., Gough J. eds. Tissue Engineering Using Ceramics and Polymers. Woodhead Publishing Ltd, Cambridge. (2007). Chapt. , 21, 445-65.

[83] Harrington, D. A, Sharma, A. K, Erickson, B. A, \& Cheng, E. Y. Bladder tissue engineering through nanotechnology. World J Urol. (2008). , 315-322.

[84] Webster, T. J. Nanomedicine: what's in a definition? Int J Nanomed. (2006). , 1, 115-116. 
[85] Thapa, A, Webster, T. J, \& Haberstroh, K. M. Polymers with nanodimensional surface features enhance bladder smooth muscle cell adhesion. J Biomed Mater Res. (2003). A: , 1374-1383.

[86] Pattison, M. A, Wurster, S, Webster, T. J, et al. Threedimensional, nanostructured PLGA scaffolds for bladder tissue replacement applications. Biomaterials. (2005). , 26, 2491-2500.

[87] Chun, Y. W, Khang, D, Haberstroh, K. M, Martin, K, \& Webster, T. J. The role of polymer nano surface roughness and submicron pores for improving bladder urothelial cell density and inhibiting calcium oxalate stone formation. Nanotechnology (2009).

[88] Shakhssalim, N, Dehghan, M. M, Moghadasali, R, Soltani, M. H, Shabani, I, \& Soleimani, M. Bladder tissue engineering using biocompatible nanofibrous electrospun constructs: feasibility and safety investigation. Urol J. (2012). Winter; , 9(1), 410-9.

[89] Thapa, A, Miller, D. C, Webster, T. J, \& Haberstroh, K. M. Nanostructured polymers enhance bladder smooth muscle cell function. Biomaterials (2003). , 24, 2915-2926.

[90] Kleinman, HK, Philp, D, \& Hoffman, .. Role of the extracellular matrix in morphogenesis. Curr Opin Biotech. 2003; 14: 526-532.

[91] Cooke, M. J, \& Philips, S. R. Shah DSH., Athey D., Lakey JH., Przyborski SA. Enhanced cell attachment using a novel cell culture surface presenting functional domains from extracellular matrix proteins. Cytotechnology. (2008). , 56, 71-79.

[92] Pattison, M, Webster, T. J, Leslie, J, Kaefer, M, \& Haberstroh, K. M. Evaluating the in vitro and in vivo efficacy of nano-structured polymers for bladder tissue replacement applications. Macromol Biosci. (2007). , 7(5), 690-700.

[93] Cook, A. D, Hrkach, J. S, Gao, N. N, Johnson, I. M, Pajvani, U. B, Cannizzaro, S. M, \& Langer, R. Characterization and development of RGD-peptide-modified poly(lactic acid-co-lysine) as an interactive, resorbable biomaterial. J Biomed Mater Res. (1997). , 35(4), 513-23.

[94] Sullivan, T. P, Eaglstein, W. H, Davis, S. C, \& Mertz, P. The pig as a model for human wound healing. Wound Repair Regen. (2001). , 9, 66-76.

[95] Auger, F. A, Rémy-zolghadri, M, Grenier, G, \& Germain, L. A truly new approach for tissue engineering: the LOEX self-assembly technique. Ernst Schering Res Found Workshop. (2002).

[96] Proulx, S, Arc, d, Uwamaliya, J, Carrier, P, Deschambeault, A, Audet, C, Giasson, C. J, Guérin, S. L, \& Auger, F. A. Germain L. Reconstruction of a human cornea by the self-assembly approach of tissue engineering using the three native cell types. Mol Vis. (2010). , 16, 2192-201.

[97] Jean, J, Lapointe, M, Soucy, J, \& Pouliot, R. Development of an in vitro psoriatic skin model by tissue engineering. J Dermatol Sci. (2009). , 53, 19-25. 
[98] Gibot, L, Galbraith, T, Huot, J, \& Auger, F. A. A preexisting microvascular network benefits in vivo revascularization of a microvascularized tissue-engineered skin substitute. Tissue Eng Part A. (2010). , 16(10), 3199-206.

[99] Bouhout, S, Perron, E, Gauvin, R, Bernard, G, Ouellet, G, Cattan, V, \& Bolduc, S. In vitro reconstruction of an autologous, watertight, and resistant vesical equivalent. Tissue Eng Part A. (2010). , 16(5), 1539-48.

[100] Chepda, T, Cadau, M, Girin, P, Frey, J, \& Chamson, A. Monitoring of ascorbate at a constant rate in cell culture: effect on cell growth. In Vitro Cell Dev Biol Anim. (2001). , 37, 26-30.

[101] Davidson, J. M. LuValle PA., Zoia O., Quaglino D. Jr., Giro M. Ascorbate differentially regulates elastin and collagen biosynthesis in vascular smooth muscle cells and skin fibroblasts by pretranslational mechanisms. J Biol Chem. (1997). , 272, 345-52.

[102] Cunha, G. R. Epithelial-stromal interactions in development of the urogenital tract. Int. Rev. Cytol. (1976).

[103] Cunha, G. R, Fujii, H, Neubauer, B. L, Shannon, J. M, Sawyer, L, \& Reese, B. A. Epithelial-mesenchymal interactions in prostatic development. I. Morphological observations of prostatic induction by urogenital sinus mesenchyme in epithelium of the adult rodent urinary bladder. J. Cell Biol. (1983).

[104] Cunha, G. R, Lung, B, \& Reese, B. Glandular epithelial induction by embryonic mesenchyme in adult bladder epithelium of Balb/c mice. Invest. Urol. (1980).

[105] Chung LWKMatsuura J., Runner MN. Tissue interactions and prostatic growth. I. Induction of adult mouse prostatic hyperplasia by fetal urogenital sinus implants. Biol. Reprod. (1984).

[106] Cunha, G. R, Battle, E, Young, P, Brody, J, Donjacour, A, Hayashi, N, \& Kinbara, H. Role of epithelial-mesenchymal interactions in the differentiation and spatial organization of visceral smooth muscle. Epithelial Cell Biol. (1992).

[107] Tanaka, S. T, Ishii, K, Demarco, R. T, \& Pope, J. C. th, Brock JW. 3rd, Hayward SW. Endodermal origin of bladder trigone inferred from mesenchymal-epithelial interaction. J Urol. (2010). , 183(1), 386-91.

[108] Liang, F. X, Bosland, M. C, Huang, H, Romih, R, Baptiste, S, Deng, F. M, Wu, X. R, Shapiro, E, \& Sun, T. T. Cellular basis of urothelial squamous metaplasia: roles of lineage heterogeneity and cell replacement. J Cell Biol. (2005). , 171, 835-44.

[109] Sun, T. T. Altered phenotype of cultured urothelial and other stratified epithelial cells: implications for wound healing. Am J Physiol Renal Physiol. (2006). F, 9-21.

[110] Heatfield, B. M, Sanefuji, H, Gerzawi, S, Urso, B, \& Trump, B. F. Surface alterations in urothelium of normal human bladder during longterm explant culture. Scan Electron Microsc. (1980). , 3, 61-70. 
[111] Varley, C. L, Stahlschmidt, J, Lee, W. C, Holder, J, Diggle, C, Selby, P. J, Trejdosiewicz, L. K, \& Southgate, J. Role of PPARgamma and EGFR signalling in the urothelial terminal differentiation programme. J Cell Sci. (2004). Pt 10): 2029-36.

[112] Baskin, L, Meaney, D, Landsman, A, Zderic, S. A, \& Macarak, E. Bovine bladder compliance increases with normal fetal development. J Urol. (1994).

[113] Haberstroh, K, Kaefer, M, Retik, A, Freeman, M, \& Bizios, R. The effects of sustained hydrostatic pressure on select bladder smooth muscle cell functions. J. Urol. (1999). , $162,2114-18$.

[114] Maizels, M. Normal and anomalous development of the urinary tract. In Walsh PC, Retik AB., Vaughan ED. Jr, Wein AJ. eds. Campbell's Urology, 7th edn. WB Saunders, Philadelphia, PA. (1998). , 308-12.

[115] Korossis, S, Bolland, F, Ingham, E, Fisher, J, Kearney, J, \& Southgate, J. Tissue engineering of the urinary bladder: considering structure-function relationships and the role of mechanotransduction. Tissue Eng. (2006). , 12, 635-44.

[116] Truschel, S. T, Wang, E, Ruiz, W. G, Leung, S. M, Rojas, R, Lavelle, J, Zeidel, M, Stoffer, D, \& Apodaca, G. Stretch-regulated exocytosis/endocytosis in bladder umbrella cells. Mol Biol Cell. (2002). , 13(3), 830-46.

[117] Wang, E, Truschel, S, \& Apodaca, G. Analysis of hydrostatic pressure-induced changes in umbrella cell surface area. Methods. (2003). , 30(3), 207-17.

[118] Yu, W, Khandelwal, P, \& Apodaca, G. Distinct apical and basolateral membrane requirements for stretch-induced membrane traffic at the apical surface of bladder umbrella cells. Mol Biol Cell. (2009). , 20(1), 282-95.

[119] Wu, T, Chen, L, Wei, T, Wang, Y, Xu, F, \& Wang, K. Effect of cyclic hydrodynamic pressure-induced proliferation of human bladder smooth muscle through Ras-related C3 botulinum toxin substrate 1, mitogen-activated protein kinase kinase 1/2 and extracellular regulated protein kinases 1/2. Int J Urol. (2012). May 10; doi:j.x., 1442-2042.

[120] Chen, L, Wei, T. Q, Wang, Y, Zhang, J, Li, H, \& Wang, K. J. Simulated Bladder Pressure Stimulates Human Bladder Smooth Muscle Cell Proliferation via the PI3K/SGK1 Signaling Pathway. J Urol. (2012). , 188(2), 661-7.

[121] Farhat, W. A, \& Yeger, H. Does mechanical stimulation have any role in urinary bladder tissue engineering? World J Urol. (2008). , 26(4), 301-5.

[122] Southgate, J, Cross, W, Eardley, I, Thomas, D. F, \& Trejdosiewicz, L. K. Bladder reconstruction-from cells to materials. Proc Inst Mech Eng. (2003). H] , 217, 311-6.

[123] Cross, W. R, Eardley, I, Leese, H. J, \& Southgate, J. A biomimetic tissue from cultured normal human urothelial cells: analysis of physiological function. Am J Physiol Renal Physiol. (2005). F, 459-68. 
[124] Baskin, L, Howard, P. S, \& Macarak, E. Effect of physical forces on bladder smooth muscle and urothelium. J Urol. (1993). Pt 2): 601-7.

[125] Adam, R. M, Eaton, S. H, Estrada, C, Nimgaonkar, A, Shih, S. C, Smith, L. E, Kohane, I. S, Bägli, D, \& Freeman, M. R. Mechanical stretch is a highly selective regulator of gene expression in human bladder smooth muscle cells. Physiol Genomics. (2004). , 20(1), 36-44.

[126] Wallis, M. C, Yeger, H, Cartwright, L, Shou, Z, Radisic, M, Haig, J, Suoub, M, Antoon, R, \& Farhat, W. A. Feasibility study of a novel urinary bladder bioreactor. Tissue Eng Part A. (2008). , 14(3), 339-48.

[127] Farhat, W, Chen, J, Erdeljan, P, Shemtov, O, Courtman, D, Khoury, A, \& Yeger, H. Porosity of porcine bladder acellular matrix: impact of ACM thickness. J Biomed Mater Res A. (2003). , 67(3), 970-4.

[128] Cartwright, L. M, Shou, Z, Yeger, H, \& Farhat, W. A. Porcine bladder acellular matrix porosity: impact of hyaluronic acid and lyophilization. J Biomed Mater Res A. (2006). , 77(1), 180-4.

[129] Bouhout, S, Gauvin, R, Gibot, L, Aubé, D, \& Bolduc, S. Bladder substitute reconstructed in a physiological pressure environment. J Pediatr Urol. (2011). , 7(3), 276-82.

[130] Cattan, V, Bernard, G, Rousseau, A, Bouhout, S, Chabaud, S, Auger, F. A, \& Bolduc, S. Mechanical Stimuli-induced Urothelial Differentiation in a Human Tissue-engineered Tubular Genitourinary Graft. Eur Urol. (2011). , 60(6), 1291-8. 
